Article

\title{
Environmental Impacts of Experimental Production of Lactic Acid for Bioplastics from Ulva spp.
}

\author{
Roel J. K. Helmes ${ }^{1}$, Ana M. López-Contreras ${ }^{1}$, Maud Benoit ${ }^{2}$, Helena Abreu ${ }^{3}$, Julie Maguire 4 (D), \\ Fiona Moejes 4 (1) and Sander W. K. van den Burg ${ }^{1, *}$ \\ 1 Wageningen University \& Research, Droevendaalsesteeg 4, 6708 PB Wageningen, The Netherlands; \\ roel.helmes@wur.nl (R.J.K.H.); ana.lopez-contreras@wur.nl (A.M. L.-C.) \\ 2 Centre d'Etude et de Valorisation des Algues (CEVA), Presqu'île de Pen Lan-BP 4, 22610 Pleubian, France; \\ maud.benoit@algaia.com \\ 3 ALGAplus, Travessa Alexandre da Conceição s/n, 3830-196 Ílhavo, Portugal; htabreu@algaplus.pt \\ 4 Bantry Marine Research Station, Gearhies, Bantry, P75 AX07 Co. Cork, Ireland; jmaguire@bmrs.ie (J.M.); \\ fmoejes@bmrs.ie (F.M.) \\ * Correspondence: sander.vandenburg@wur.nl; Tel.: +31-70-3358-129
}

Received: 13 June 2018; Accepted: 7 July 2018; Published: 13 July 2018

\begin{abstract}
An exploratory Life Cycle Assessment (LCA) was carried out to provide insight into the environmental impacts of using the green seaweed Ulva spp. as a feedstock, for production of bioplastic. The study focused on the production of lactic acid as a precursor of polylactic acid. The study was on the production process: (1) The cultivation of Ulva spp., in an Integrated Multitrophic Aquaculture system; (2) the processing of the biomass for solubilization of sugars; (3) the fermentation of the sugars to lactic acid; (4) the isolation of lactic acid from fermentation broth. The study identified environmental hotspots and compared an experimental seaweed production chain with conventional feedstocks. The main hotspot is derived from electricity consumption during seaweed cultivation. The impact of electricity consumption can be lowered by reducing energy use and sourcing renewable energy, and by improving the material efficiency in the product chain. To improve understanding of the process of production's environmental impacts, future studies should broaden the system boundaries and scope of sustainability issues included in the environmental assessment.
\end{abstract}

Keywords: bioplastics; seaweed; lactic acid; Life Cycle Assessment; Ulva spp.

\section{Introduction}

Europe produced 58 million tons of plastics in 2015 [1], corresponding to $18 \%$ of the global production. The most common polymers used for plastic production are derived from petrochemicals. Concerns regarding depleting fossil fuel resources, recyclability, and biodegradability of these conventional plastics have led to considerable effort to produce plastics from renewable biomass.

Terrestrial crops, such as corn, wheat, sugar beets and sugar cane are currently the main feedstock for the production of bioplastics [2-4]. One type of bioplastic is polylactic acid (PLA), a highly versatile, biodegradable, aliphatic polyester derived from renewable resources, (such as corn and sugar beets $[5,6])$.

There is a growing concern that the use of feedstock for bioplastics will compete with its use as food, feed or fuel production, which will subsequently increase the raw material costs, as well as negatively impact the environment $[7,8]$. To overcome the food, feed and fuel versus bioplastics predicament, novel feedstocks must be sought. 
One potential source is seaweed. Seaweeds, also known as macro-algae, are photosynthetic macroorganisms, able to convert carbon dioxide $\left(\mathrm{CO}_{2}\right)$ into carbohydrates, lipids, proteins and other cellular components. These items can be created into or combined with potential biofuel, foods, feeds, and other intermediate compounds. They have many valuable, bioactive applications [9]. Seaweeds are produced in offshore and onshore systems, and various usages of seaweeds are currently investigated. These usages range from food and bio-stimulants to cosmetics and biofuels [10,11].

Seaweed feedstock for bioplastic applications can have benefits over land-based feedstock such as sugarcane and maize. Seaweed's growth rate, productivity per land surface area, and carbohydrate yield per surface area are all higher than traditional feedstocks [12]. In particular, green seaweeds contain comparatively higher levels of accessible sugars, including starch and cellulose [13]. When grown on land in ponds, seaweeds can be induced to produce even more carbohydrates through manipulation of their production factors.

The goal of this study is to estimate the environmental impacts of producing lactic acid and its co-products from the green seaweed Ulva spp.; by identifying environmental hotspots and opportunities for improvement, we hope to encourage its use as a feedstock. The study also investigates which environmental impacts would be avoided if the co-products substituted other, more harmful alternatives. This would benefit the development of this chain as well.

\section{Materials and Methods}

\subsection{System Description}

\subsubsection{Seaweed Cultivation}

Ulva spp. was selected as feedstock for production of bioplastic precursors due to its composition: It is rich in sugars and proteins [14] and has a relatively low salt content. Several studies have shown the successful cultivation of Ulva spp. under Integrated Multi-Trophic Aquaculture (IMTA) conditions $[15,16]$.

Ulva spp. was grown in a land-based IMTA system, where nutrient enriched water (nitrate, $\mathrm{CO}_{2}$ and ammonia) from adjacent semi-intensive sea bream and sea bass farms provided all of the essential nutrients for the cultivation of the seaweed. This allowed for consistent high biomass yields without the use of artificial fertilizers nor the addition of $\mathrm{CO}_{2}$ to the water. In order to maximize starch yields, the IMTA-conditions were followed by conditions of N-deprivation. During this period, water flows were cut, and electricity was only used for bottom-aeration of the seaweed basins. After a pilot trial in $1000 \mathrm{~L}$ tanks, under nitrogen-depleted conditions, Ulva spp. biomass had a starch content of up to $25 \%$ of dry weight in the commercial scale IMTA system of ALGAplus in Ílhavo, Portugal (20,000 L tanks).

\subsubsection{Seaweed Processing}

The produced Ulva spp. was hydrolyzed according to the two-step approach developed in the SEABIOPLAS project. Enzymatic and acidic hydrolysis are common approaches in the treatment of land-based feedstocks for starch hydrolysis to produce first generation bioethanol production [17-19]. Ulva spp. biomass was subjected to enzymatic hydrolysis with commercially available starch degrading enzymes (spirizyme $\odot$, liquozyme $\odot$ ), which prevented sugar degradation and inhibitor formation. Subsequently, an acid hydrolysis step ( $\mathrm{pH} 0.88$ ) was conducted, where sulfuric acid (96\%) hydrolyzed Ulvans and decreased viscosity. The hydrolysate for fermentation contained glucose $(26.7 \mathrm{~g} / \mathrm{L}$ total glucose of which $25.0 \mathrm{~g} / \mathrm{L}$ as monomeric glucose), rhamnose ( $4.1 \mathrm{~g} / \mathrm{L}$ total rhamnose in polymeric form) and xylose ( $2.7 \mathrm{~g} / \mathrm{L}$ total xylose of which $1.5 \mathrm{~g} / \mathrm{L}$ as monomeric xylose) as fermentable sugars, and reflected a yield of $0.75 \mathrm{~g}$ fermentable monosaccharides/g starch. The hydrolysis of Ulva spp. yielded the hydrolysate and the hydrolysate residue.

The hydrolysate of Ulva spp. was fermented by Lactobacillus plantarum (DSM 20174), which resulted in the production of $0.9 \mathrm{~g}$ lactic acid/g monomeric sugar consumed. The hydrolysate fermented 
well and did not require additional or supplemental nutrients. Lactic acid produced in the seaweed-derived growth medium can be extracted using standard basic precipitation with calcium sulfate (gypsum) as a co-product. Depleted fermentation broth is considered bio-waste and was treated by anaerobic digestion. Anaerobic digestion can be considered a useful application, since it provides energy and digestate, though other treatments may extract higher-value products from the fermentation broth (e.g., fish feed).

\subsection{Goal and Scope}

The aim of this paper is to identify the environmental hotspots of the conversion of the seaweed Ulva spp. into lactic acid (LA) in the current experimental setup. For this purpose, the Life Cycle Assessment methodology was used with primary data collected in the SEABIOPLAS project. SEABIOPLAS was a European Commission funded research project that aimed to prove the feasibility of producing lactic acid from Ulva spp. cultivated in an Integrated Multitrophic Aquaculture (IMTA) systems [20,21]. The standard four-step Life Cycle Assessment (LCA) approach [22] was followed in this study.

The functional unit was defined as " $1 \mathrm{~kg}$ of purified lactic acid (LA) and its co-products, at the bioprocessing laboratory", abbreviated to " $1 \mathrm{~kg}$ of LA". The lactic acid produced is an intermediate product, which can be applied to the production of several functional materials. When polymerized into PLA, it can be used in packaging films.

To investigate the current experimental supply chain, the base case scenario (LA1) models all steps from the initial cultivation of Ulva spp. up to the lactic acid purification, as done in the experimental supply chain. The base case scenario is compared with two other scenarios (see Table 1). The piloted optimizations of Ulva spp. cultivation and of lactic acid purification were modelled in scenario LA2. The influence of the feedstock was tested with scenario LA3 by modelling maize grain input in the experimental hydrolysis and fermentation steps. In discussing the results, a comparison between lactic acid from seaweed and lactic acid from land-based feedstocks is made, (based on prior studies.)

Table 1. Main characteristics of the three scenarios studied with Life Cycle Assessment.

\begin{tabular}{cccc}
\hline Scenario & LA1 & LA2 & LA3 \\
\hline $\begin{array}{c}\text { Species used (and part) } \\
\text { Biomass production }\end{array}$ & Ulva spp. (whole) & Ulva spp. (whole) & Zea mays (grains) \\
$\begin{array}{c}\text { Hydrolysis } \\
\text { IM Fermentation } \\
\text { Purification }\end{array}$ & Experimental & IMTA (experimental, optimized & Conventional agriculture \\
for starch enrichment) & Experimental & Experimental (theoretical) \\
\end{tabular}

\subsection{System Boundaries}

The scope of this assessment was limited to the experimental chain from land-based cultivation to lactic acid isolation, with the aim to investigate the state of the technology utilized within the SEABIOPLAS project. No extrapolations were made to assume higher efficiencies due to larger volumes or technical development. It was assumed that all steps of the Ulva spp. production took place as one uninterrupted chain of unit operations in Illhavo, Portugal, where the seaweed cultivation took place. In this supply chain set-up, periods of time where equipment was idle, as well as cooling and transportation of intermediate materials does not occur. The machinery, equipment and other capital goods were excluded from the assessment, since the properties and use intensity of the experimental equipment in which the biomass conversions were done, could not be estimated. All raw materials and energy that were needed from outside the experimental production chain were included in the study.

PLA film was not chosen as functional unit for two reasons: (1) Polymerization to alkyd resins was piloted for coatings applications in the SEABIOPLAS project, hence no primary data were available 
on PLA; (2) secondary industrial data of lactic acid polymerization as a separate step were unavailable. Data were only available in aggregated, cradle-to-gate format [3,4].

Effects of human activities at or near the sea on marine biodiversity and on marine biotic resource availability have been described qualitatively [23], but a directly applicable quantitative method has yet to be developed.

\subsection{Multifunctionality}

Multifunctionality is the phenomenon describing a process operation that provides multiple products. It occurs at three places in the particular system studied: (1) The IMTA system produces fish and Ulva spp. during biomass processing; (2) hydrolysis residue; (3) gypsum are also produced.

In the IMTA system, both fish and seaweed was grown in one system with some linked resource flows. For the IMTA system, only the flows that directly go to the seaweed production were included in the LCA (a subdivision approach was taken). Water flows and electricity use for fish basins and nutrients from wasted or digested fish feed were not included, since these inputs and outputs are not influenced by the seaweed production activity.

A system expansion approach was taken for the co-products from biomass processing, compliant with the European Commission Joint Research Centre Institute for Environmental Sustainability (EC-JRC-IES) [24]. The hydrolysis of fresh Ulva spp. resulted in a liquid hydrolysate for fermentation, and a solid nutrient-rich residue. This residue contained all components of the whole Ulva spp. except for the extracted polysaccharides. In this study, it was assumed that the hydrolysis residue could partially replace protein soy in European sea bass feed, based on studies that confirm that Ulva spp. proteins can contribute up to $15 \%$ of the total protein requirement without compromising growth performance [25]. The amount of replaced soy was determined by using the nitrogen contents of Ulva spp., maize and soy as a proxy for their protein contents.

After the fermentation of the Ulva spp. hydrolysate, lactic acid can be purified from the solution by precipitation with calcium hydroxide, yielding calcium sulfate (gypsum). The gypsum obtained from the precipitation was assumed to substitute the conventional gypsum as a building material on a one-to-one basis.

\subsection{Data Collection and LCI Modelling}

To conduct the LCA analysis, data on a number of variables were collected (see Table 2 for an overview of variables). 
Table 2. Variables for Life Cycle Analysis (LCA) analysis.

\begin{tabular}{|c|c|}
\hline Phase & Variables \\
\hline Biomass production & $\begin{array}{l}\text { Dry matter content }(\% \mathrm{WM}) \\
\text { Starch content }(\% \mathrm{WM}) \\
\text { Starch content }(\% \mathrm{DM}) \\
\text { Direct land occupation }\left(\mathrm{m}^{2 \times} \text { year }\right) \\
\text { Electricity use }(\mathrm{kWh}) \\
\text { Diesel use }(\mathrm{kWh}) \\
\text { On-site use of pick-up truck }(\mathrm{km})\end{array}$ \\
\hline Biomass processing & $\begin{array}{l}\text { Biomass used (kg WM) } \\
\text { Biomass used (kg DM) } \\
\text { Hydrolysis yield }(\%) \\
\text { Fermentation yield }(\%) \\
\text { LA purification yield }(\%) \\
\text { Starch used }(\mathrm{kg}) \\
\text { Direct electricity use }(\mathrm{kWh} / \mathrm{kg} \mathrm{LA}) \\
\text { Sulfuric acid, concentrated }(\mathrm{kg}) \\
\text { Hydrochloric acid }(1 \mathrm{M}, \mathrm{kg}) \\
\text { Calcium carbonate }(\mathrm{kg}) \\
\text { Enzyme mix for hydrolysis }(\mathrm{kg}) \\
\text { Monoammonium phosphate }(\mathrm{kg}) \\
\text { Ammonium sulfate }(\mathrm{kg}) \\
\text { Calcium hydroxide }(\mathrm{kg}) \\
\text { Purified water (also waste water, } \mathrm{L}) \\
\text { Biowaste produced }(\mathrm{kg}) \\
\mathrm{N} \text { content in biomass }(\% \mathrm{DM})\end{array}$ \\
\hline
\end{tabular}

Table 2. Variables for Life Cycle Analysis (LCA) analysis.

\begin{tabular}{cl}
\hline \multicolumn{1}{c}{ Phase } & \multicolumn{1}{c}{ Variables } \\
\hline & N in residue $(\mathrm{kg})$ \\
Hydrolysis byproduct & N content in soy $(\% \mathrm{DM})$ \\
& Substituted soy $(\mathrm{kg})$ \\
\hline Purification byproduct & Gypsum $(\mathrm{kg})$ \\
\hline
\end{tabular}

Primary data on the resources used in the production process was provided by the project partners involved in the experimental processes (see Table 3). The amounts of electricity required for hydrolysis, fermentation, and lactic acid purification, were estimated as conservative industrial usages, by the researchers of each process, followed by a cross-check with Reference [26].

SimaPro 8.4.0.0 (Pré Consultants, Amersfoort, The Netherlands) was used to derive the life cycle inventory (LCI) and characterize the impacts. Cultivation, hydrolysis, fermentation, and purification, were modeled as four separate unit processes using the data reported by the project partners (see Table 3). So-called system models, which contain partial LCIs for the reference flow they cover, were taken from EcoInvent 3.3 [27] for the used resources, including the global average impact of maize cultivation. The Portuguese electricity production was modeled separately, using information from the International Energy Agency [28] and the system models from EcoInvent 3.3 of individual electricity generation technologies. They were then connected to the four unit processes. The enzyme production impacts were taken from Reference [29]. This procedure resulted in a supply chain model consisting of several linked processing steps with partial LCIs for each supplied resource. The SimaPro software was used to translate this model to one overall LCI for the production of $1 \mathrm{~kg}$ of LA and its co-products, for each respective scenario. 
Table 3. Data sources for each step of the production process.

\begin{tabular}{ll}
\hline Description & Data Source \\
\hline Cultivation of Ulva spp. & ALGAplus \\
Hydrolysis of Ulva spp., yielding hydrolysate and residue & CEVA \\
Fermentation of hydrolysate to lactic acid & Wageningen University \& Research (experimental) \\
Purification of lactic acid from fermentation broth & Wageningen University \& Research (expert \\
Chemicals (cultivation operation, salts, acids, bases), maize cultivation & judgment) \\
Electricity & {$[27]$} \\
Enzymes for hydrolysis & {$[27,28]$} \\
\hline
\end{tabular}

\subsection{Life Cycle Impact Assessment}

To identify hotspots, the impact characterization method ReCiPe 2008 [30] was used, as it has weighting and normalization factors that enable comparison of different environmental impacts. The commonly used Hierarchist version was used for midpoint characterization, while European normalization factors and average weighting factors were used for endpoint characterization.

\section{Results}

\subsection{Inventory of Resource Use}

Table 4 gives an overview of resource use, yields and mass ratios for biomass production, as well as biomass processing and residues in each of the production step. This is provided by project partners (for LA1 and LA2) and derived from literature (for LA3). All mass amounts are LA3 expressed per $1 \mathrm{~kg}$ lactic acid produced. Dry matter and starch content of maize was taken from Reference [4]. For electricity and diesel usage during maize cultivation, LA3 represents the total consumptions for the lifecycle of dried maize, taken from EcoInvent 3.3 [27]. Direct electricity and diesel usage are listed for the Ulva spp. Cultivations are listed in LA1 and LA2. Nitrogen contents of maize and soy were taken from Reference [31]. 
Table 4. Inventory of resource, energy and biomass consumptions and byproduct productions, relative to $1 \mathrm{~kg}$ of Lactic Acid production for each of the three scenarios (WM = Wet Biomass, DM = Dry Biomass).

\begin{tabular}{|c|c|c|c|c|}
\hline & Scenario & LA1 & LA2 & LA3 \\
\hline \multirow{7}{*}{$\begin{array}{c}\text { Biomass } \\
\text { production }\end{array}$} & Dry matter content (\%WM) & 8.5 & 15 & 85 \\
\hline & Starch content $(\% \mathrm{WM})$ & 1.7 & 6.0 & 58 \\
\hline & Starch content (\%DM) & 20 & 40 & 68 \\
\hline & Direct land occupation $\left(\mathrm{m}^{2 \times}\right.$ year $\left./ \mathrm{kg} \mathrm{WM}\right)$ & 0.07 & 0.07 & 0.7 \\
\hline & Electricity use $(\mathrm{kWh} / \mathrm{kg} \mathrm{WM})$ & 8.2 & 8.2 & 1.1 \\
\hline & Diesel use (kWh/kg WM) & 0.012 & 0.012 & 0.022 \\
\hline & On-site use of pick-up truck (km/kg WM) & 2.1 & 0.33 & n.a. \\
\hline \multirow{17}{*}{ Biomass processing } & Biomass used (kg WM) & 158 & 25 & 4.6 \\
\hline & Biomass used (kg DM) & 13 & 3.7 & 3.9 \\
\hline & Hydrolysis yield $(\%)$ & 75 & 75 & 75 \\
\hline & Fermentation yield $(\%)$ & 90 & 90 & 90 \\
\hline & LA purification yield (\%) & 56 & 99 & 56 \\
\hline & Starch used $(\mathrm{kg})$ & 2.0 & 1.2 & 2.0 \\
\hline & Direct electricity use (kWh/kg LA) & 13.7 & 13.5 & 13.7 \\
\hline & Sulfuric acid, concentrated $(\mathrm{kg})$ & 5.0 & 1.7 & 5.0 \\
\hline & Hydrochloric acid $(1 \mathrm{M}, \mathrm{kg})$ & 1.7 & 0.27 & 1.7 \\
\hline & Calcium carbonate $(\mathrm{kg})$ & 57 & 9.0 & 57 \\
\hline & Enzyme mix for hydrolysis $(\mathrm{kg})$ & 0.38 & 0.060 & 0.38 \\
\hline & Monoammonium phosphate (kg) & 0.058 & 0.033 & 0.058 \\
\hline & Ammonium sulfate $(\mathrm{kg})$ & 0.10 & 0.057 & 0.10 \\
\hline & Calcium hydroxide $(\mathrm{kg})$ & 1.47 & 0.83 & 1.47 \\
\hline & Purified water (also waste water, L) & 21 & 18 & 21 \\
\hline & Biowaste produced $(\mathrm{kg})$ & 20 & 20 & 20 \\
\hline & $\mathrm{N}$ content in biomass $(\% \mathrm{DM})$ & 1.5 & 4.9 & 2.3 \\
\hline \multirow{3}{*}{$\begin{array}{l}\text { Hydrolysis } \\
\text { byproduct }\end{array}$} & $\mathrm{N}$ in residue $(\mathrm{kg})$ & 0.20 & 0.19 & 0.089 \\
\hline & $\mathrm{N}$ content in soy $(\% \mathrm{DM})$ & 7.5 & 7.5 & 7.5 \\
\hline & Substituted soy (kg) & 2.7 & 2.4 & 1.2 \\
\hline $\begin{array}{l}\text { Purification } \\
\text { byproduct }\end{array}$ & Gypsum (kg) & 0.95 & 0.95 & 0.95 \\
\hline
\end{tabular}

\subsection{ReCiPe Environmental Score}

The aggregated environmental impact is expressed as the ReCiPe score, written in $\mathrm{mPt}$ (millipoints). The score is a weighted aggregation of seventeen environmental impact categories covering three areas: Human health, ecosystems and resource depletion. Human health damage due to climate change contributes $42 \%$ to the total impact score of scenario LA1, as shown in Figure 1a; it is caused by the electricity consumption during cultivation and to a lesser extent by direct emissions in the hydrolysis. Other major impacts are exclusively caused by electricity consumption: $32 \%$ of the impact score of LA1 is determined by fossil resource depletion, and $14 \%$ is due to particulate matter formation. Minor impacts are human toxicity and damage to ecosystems due to climate change (contributing 5\% and 4\%, respectively). The remaining impact ("Rest" in Figure 1a) amounts to 3\% and is determined by agricultural land occupation and metal depletion. The hydrolysis residue and gypsum from purification would replace soy in fish feed and conventional gypsum, respectively. The impacts of these replaced products amount to less than $1 \%$ of the total impact and are not shown in the results. 


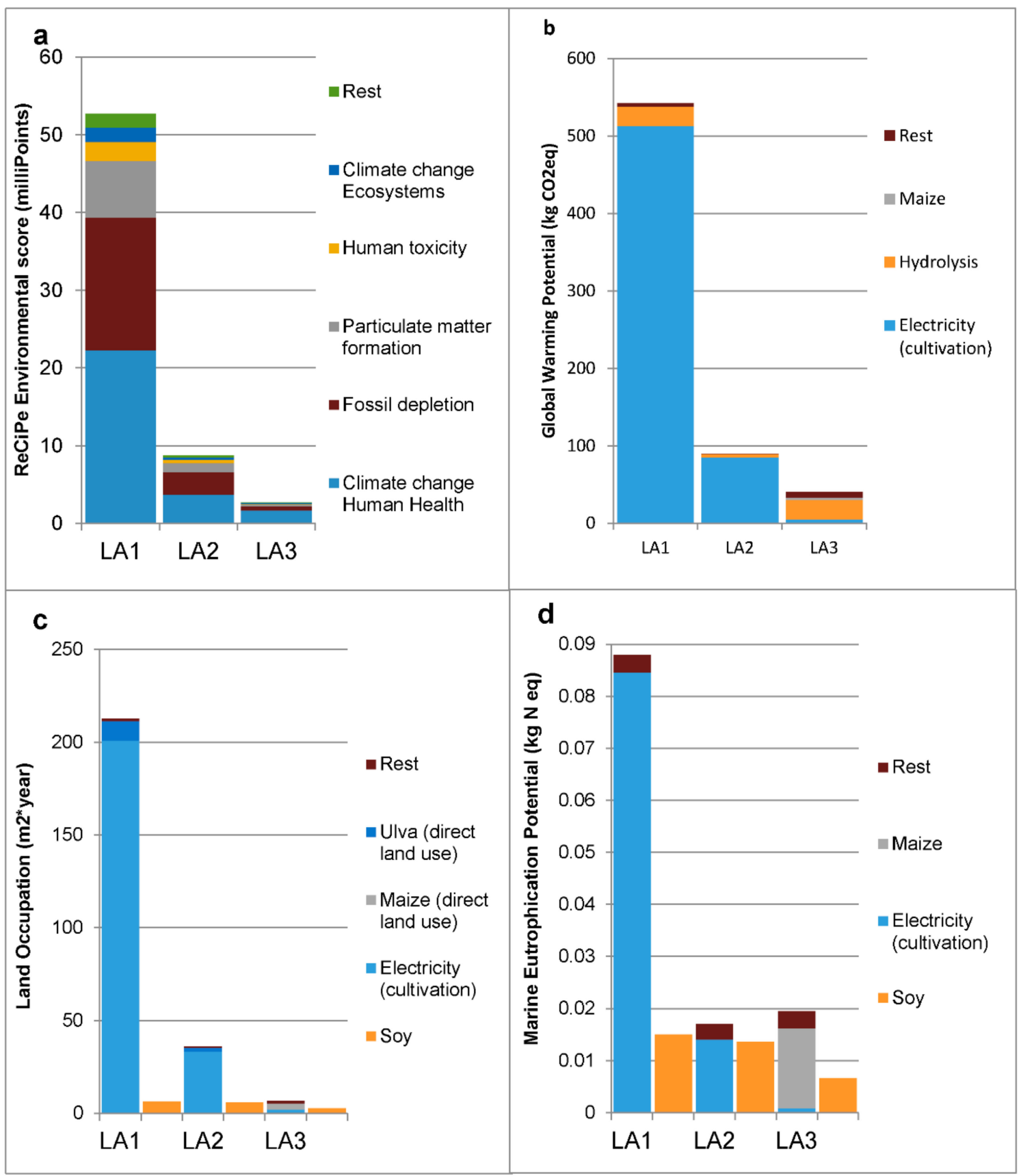

Figure 1. Life Cycle Impact Assessment results for the three scenarios (a) Weighted and aggregated environmental impact using the ReCiPe method (b) climate change, (c) land use, and (d) marine eutrophication. Every second column in Figure 1c,d indicates the impact of the soy production that is avoided if the hydrolysis residue is used in fish feed to partially replace soy, for each scenario.

Optimization of Ulva spp. cultivation and lactic acid purification (LA2) reduces the electricity demand significantly, as less Ulva spp. is needed to yield the same amount of lactic acid. Thus, the ReCiPe environmental score decreases considerably. Use of maize as feedstock (LA3) shows a lower ReCiPe environmental score, emphasizing the large influence of the current experimental Ulva spp. cultivation on the total impact. 


\subsection{Global Warming Potential}

The global warming potential (GWP, Figure 1b) demonstrates that electricity use is dominant in climate change impacts. $99 \%$ of the electricity consumption occurs during cultivation, for water pumping (2-3 weeks) and aeration of the tanks (4-5 weeks). A secondary contribution to climate change is due to direct emissions of $\mathrm{CO}_{2}$ from the use of carbonate as a neutralization base in the hydrolysis of the biomass. Other resources add up to a climate change contribution of $1 \%$ in LA1 and were grouped in the category "Rest". The substitution of soy in fish feed by the hydrolysis residue would save $6.7 \mathrm{~kg} \mathrm{CO} 2 \mathrm{eq} / \mathrm{kg}$ LA, which is an insubstantial reduction compared to the total GWP (shown in the Figure 1b). Substitution of conventional gypsum with gypsum from the LA purification has no significant effect on the GWP. When the Ulva spp. cultivation and lactic acid purification is further optimized (LA2), the electricity demand can also be reduced significantly, as less Ulva spp. is needed to yield the same amount of lactic acid. The direct emission in the hydrolysis is also reduced because the starch is more concentrated in the Ulva spp., while the same reaction conditions are used. When maize (Zea mays) is used as a feedstock instead of Ulva spp. (LA3), the GWP is significantly lower.

\subsection{Land Occupation}

While urban land occupation is limited $\left(6.1 \mathrm{~m}^{2} \mathrm{a}\right.$ for scenario LA1), the agricultural land occupation is substantial, with $206 \mathrm{~m}^{2}$ a (Figure 1c) for LA1. This land is largely used for growing biomass for the generation of electricity. The Ulva spp. cultivation facility is the second largest contribution to agricultural land occupation, since the Ulva spp. is cultivated on land in the current production setup. The land required for Ulva spp. cultivation was classified as "agricultural", because of its rural location, although the current production site, consisting of abandoned salt pans and aquaculture ponds on land, is more suitable for aquaculture than for agricultural purposes.

Substitution of soy in fish feed by the hydrolysis residue would save land in scenario LA1 $\left(6.3 \mathrm{~m}^{2} \mathrm{a}\right.$, Figure 1c) and to a lesser extent in LA2 (5.7 $\left.\mathrm{m}^{2} \mathrm{a}\right)$. In scenario LA2, less Ulva spp. is hydrolyzed for the same amount of sugar for the fermentation, which is partially compensated by a higher protein content in the Ulva spp. of LA2. Less land would be saved by using the residue from maize hydrolysis (LA3) because the protein content of maize is lower than that of Ulva spp., and less maize is needed to provide the same amount of sugar for the fermentation. Substitution of conventional gypsum with gypsum from the LA purification would hardly reduce land occupation.

\subsection{Marine Eutrophication}

Marine eutrophication impacts were characterized by using the ReCiPe midpoint method. The largest contribution to the nitrogen emissions causing marine eutrophication comes from electricity consumption (LA1 and LA2) and maize cultivation (LA3) (Figure 1). Under optimized Ulva spp. cultivation (LA2), the total impact of producing soy for fish feed alone is almost the same as that of producing the hydrolysis residue for fish feed as a byproduct of lactic acid. Substitution of soy in fish feed by the hydrolysis residue would reduce nitrogen emissions: the nitrogen emissions from electricity production in Portugal would be compensated by avoiding emissions from soy production for fish feed. Elaborating on this consequential line of thought would require a more detailed assessment. Substitution of conventional gypsum with gypsum from the LA purification would hardly reduce nitrogen emissions.

\subsection{Hotspot Identification and Sensitivity Analysis}

The electricity consumption during the Ulva spp. cultivation is the most important environmental hotspot, with a $97 \%$ contribution to the ReCiPe score of scenario LA1. Electricity use during cultivation drives the environmental impact. The direct $\mathrm{CO}_{2}$ emission from the hydrolysis contributes $2 \%$ and is a secondary hotspot. The remainder of all processes in the life cycle contributes approximately $1 \%$, in which the treatment of bio-waste from the fermentation has the largest contribution. 
Electricity use can be reduced in two ways. First, an electricity use reduction of $10 \%$ in LA1 results in a similar reduction in the ReCiPe score. Furthermore, optimized cultivation and purification in scenario LA2 reduces the amount of Ulva spp. required for $1 \mathrm{~kg} \mathrm{WM}$ of lactic acid by a factor of six, which reduces the required amount of electricity with the same factor. The environmental impacts are sensitive to the yields in all steps in the supply chain.

The impact of electricity can also be reduced, through alternative energy sources. This was studied by replacing the total electricity supply in the production chain with the Portuguese mix of renewable electricity technologies, consisting of wind, solar, biomass and hydro-energy. The ratios between the renewable technologies were kept the same as in the overall grid mix, following Reference [28]. Since the fossil-based generation technologies (i.e., hard coal, natural gas and oil) contribute $80 \%$ of the electricity's impact, their exclusion would strongly reduce the environmental impact of lactic acid. The GWP is reduced from $0.11 \mathrm{~kg} \mathrm{CO} 2 \mathrm{eq} / \mathrm{kWh}$ to $0.013 \mathrm{~kg} \mathrm{CO} 2 \mathrm{eq} / \mathrm{kWh}$, while the agricultural land occupation is increased from $0.043 \mathrm{~m}^{2} \mathrm{a} / \mathrm{kWh}$ to $0.071 \mathrm{~m}^{2} \mathrm{a} / \mathrm{kWh}$. Electricity use had a large contribution to several impact indicators in scenarios LA1 and LA2, (such as fossil resource depletion and marine eutrophication), therefore a substitution of electricity source resulted in very strong changes, as shown in Figure 2.

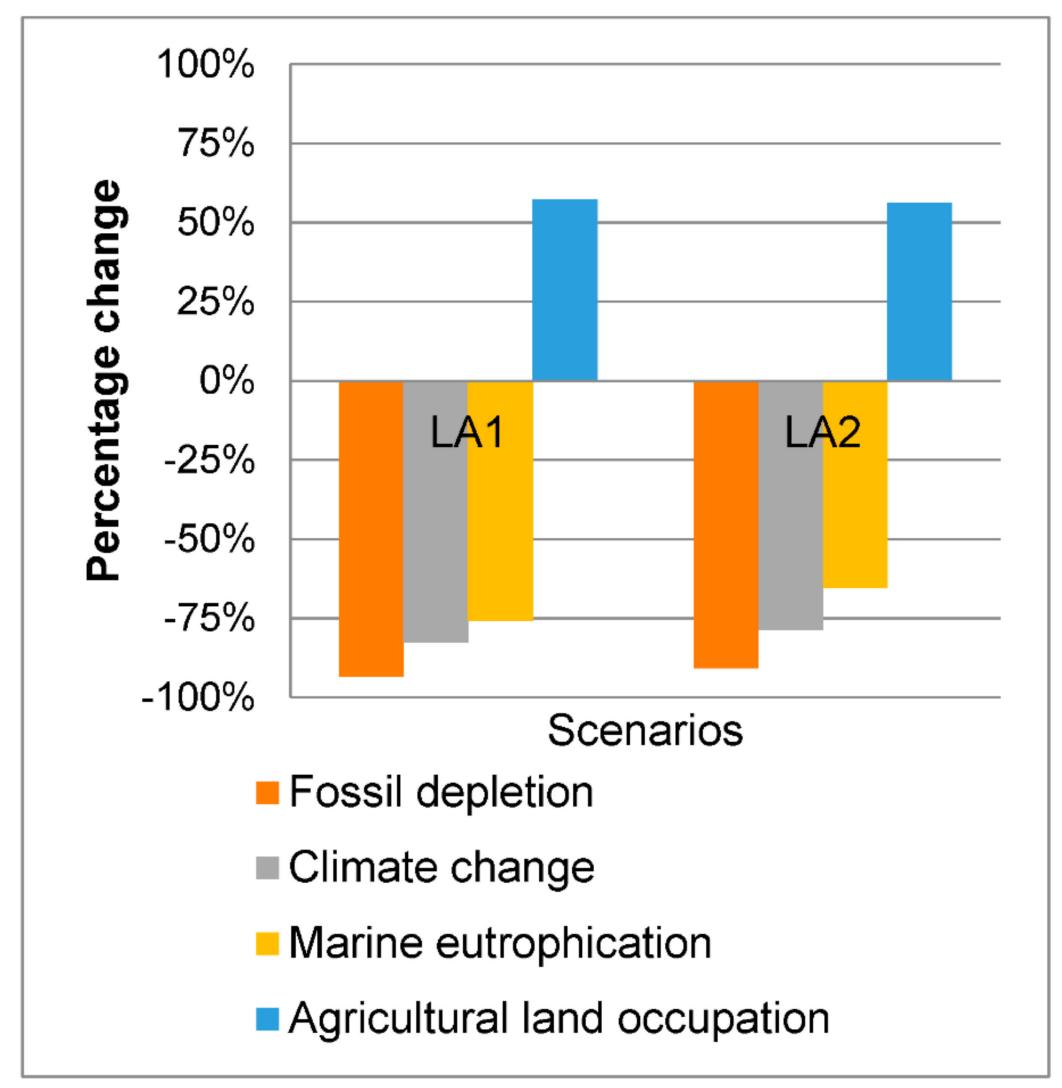

Figure 2. Percentage change in four impact categories in scenarios LA1 and LA2 due to switch from average Portuguese electricity to renewable electricity for the three scenarios.

\subsection{Comparison with Other Feedstocks}

The use of Ulva spp. can be compared with other feedstocks for lactic acid production. The results of scenario LA3 (Figure 1) show that, under the same processing conditions, maize has a significantly lower environmental impact than Ulva spp. because of the large electricity consumption used in producing the latter. LA2 demonstrates that the piloted improvements can achieve a feedstock efficiency gain from $158 \mathrm{~kg} \mathrm{WM} / \mathrm{kg}$ LA to $25 \mathrm{~kg} \mathrm{WM} / \mathrm{kg}$ LA, bringing the environmental impact of Ulva spp.-based LA closer to that of maize-based LA. 
The contribution of Ulva spp. cultivation to agricultural land occupation is reduced from $11 \mathrm{~m}^{2} \mathrm{a} / \mathrm{kg}$ LA in LA1 to $1.7 \mathrm{~m}^{2} \mathrm{a} / \mathrm{kg}$ LA in LA2, compared with $3.3 \mathrm{~m}^{2} \mathrm{a} / \mathrm{kg}$ LA for maize production in LA3. The contribution of electricity in the Ulva spp. cultivation remains substantial for both LA1 and LA2 (140 and $23 \mathrm{~m}^{2} \mathrm{a} / \mathrm{kg}$ LA, respectively), while electricity use hardly plays a role in maize cultivation.

\section{Discussion}

\subsection{Uncertainties and Improvements}

Due to the experimental character of the production chain, technical and methodological uncertainties complicate the assessment of the current and future production systems. These are discussed below.

An influential uncertainty in this study is how the Ulva spp. residue from the hydrolysis is applied. The current assumption is that the residue partially replaces soy in fish feed. An alternative use of different components of the residue, as pigments or active pharmaceutical ingredients, could have a greater economic and environmental potential.

The carbon dioxide fixed in the end product represents a second uncertainty. It is subtracted from the total greenhouse gas emissions, under the assumption that the carbon from the atmosphere is stored in the end product. This is a common approach, followed by [4,32], which assumes that if $1 \mathrm{~kg}$ of bioplastics degrade at the end of its life and releases its carbon to the atmosphere, another $\mathrm{kg}$ of bioplastics is produced elsewhere that stores the carbon from its biomass feedstock. In this study, the effects are limited, as the carbon credit is $1.47 \mathrm{~kg} \mathrm{CO} 2 \mathrm{eq} / \mathrm{kg}$ LA when compared to the overall GWP of $513 \mathrm{~kg} \mathrm{CO} 2 \mathrm{eq} / \mathrm{kg}$ LA for scenario LA1. Studies that include the end-of-life phase of the product elaborate how the bioplastics are distributed over waste flows and subsequent releases of carbon to the atmosphere [33].

The third uncertainty is about the benefits of nitrogen and phosphorus fixed in the Ulva spp. By assuming that all nutrients end up in the residue during hydrolysis, the benefits are reflected in the substitution of soy in fish feed. In contrast to carbon, no benefits were granted to nutrient fixation in the Ulva spp., as nutrients were not stored away from the sea for a significant period: Because the fish digest the residue supplemented in the fish feed, the nutrients are excreted back into the sea. If the nitrogen would be fixated for a longer period, this would be a significant reduction of the marine eutrophication. Storing phosphorus for a longer period would not translate into less marine eutrophication, since the current LCA characterization method assumes that marine biotic production is limited by nitrogen in general.

\subsection{Expected Effects of Upscaling to Industrial Production}

The path from an experimental production chain to a large-scale industrial chain is uncertain but improvements in the individual steps can result in substantial improvements. Hottle et al. [33] makes predictions based on microalgae. Through forecasting both optimization from small-scale to large-scale, and improved recycling and reuse of waste streams, they predict that a difference of two orders of magnitude can be bridged between small-scale microalgae technology and the reference of large-scale soy production [34]. Open seaweed farming systems for bioenergy seem very favorable with net carbon, as well as nutrient uptake and positive energy balances, especially when early stage results are extrapolated to an upscaled scenario [35].

\subsection{Improvement Opportunities for Technology}

Several improvements not yet implemented in the production chain can alter the outcome of the LCA. Material efficiency can be improved by adjusting the hydrolysis and the fermentation. In the hydrolysis, reducing the excess of acid used would reduce the amount of neutralization base needed, thus reducing the direct $\mathrm{CO}_{2}$ emissions from hydrolysis. In addition, the use of an alternative base to sodium carbonate (for neutralization after hydrolysis) would eliminate these emissions. 
The fermentation yield of Ulva spp. hydrolysate can be improved further by increasing the starch content and by lowering the salt content. Washing the Ulva spp. directly after harvest would reduce the salt content and consequentially the salt content in the hydrolysate. Washing would increase water and energy use in the production chain but may be beneficial from an environmental point of view.

The hydrolysis residue can also be used for higher value applications, especially if the hydrolysis of the Ulva spp. is part of a cascading biorefinery approach. Such an approach would maximize the total value of the Ulva spp. biomass [36]. Whole seaweed has been historically used as a fertilizer and a soil conditions improver [37,38]; the residue could fulfil the same role [38]. Seaweed can be used as a feed additive due to its prebiotic compounds, which may even help to enhance livestock production and health [39]. A recent Ulva spp. based biorefinery process has been described, where the carbohydrates are fermented to acetone, butanol, ethanol and 1,2-propanediol, and the protein rich fraction is used as animal feed [40]. The nutrients taken from the sea would be stored in a livestock production chain more permanently than in fish production, thus reducing marine eutrophication. Seaweeds and their derivatives may also be used for high value applications such as pharmaceuticals [41], food and food additives [42].

While the improvement opportunities can be clearly identified, a best-case scenario beyond scenario LA2 cannot be quantified, as too little is known about technical scaling effects and the potential for radical innovation in both Ulva spp. production and further processing of all coproducts. The potential reduced impacts and positive effects of improved Ulva spp. cultivation and application can be proven with an assessment of the complete life cycle of all coproducts.

\subsection{Broadening the Sustainability Assessment}

Many interactions between seaweed cultivation and the status of the marine ecosystems are still hard to quantify with LCA. Existing characterization methods need to be improved to include exchanges within the sea, such as toxicity impacts and the role of phosphorus in marine eutrophication. Although assessments of benthic impacts, by-catch, emissions from anti-fouling paints and biotic resource use have all been studied in LCAs on fisheries and aquaculture, it is common to focus on traditional environmental impact categories [43]. Novel characterization methods should be developed for less studied impacts, such as those described by Langlois et al. [23], including biotic resource use, invasive species, seafloor destruction, artificial habitat creation, shading, turbidity and sedimentation, noise and original habitat loss.

The cultivation in this system has a strong relation with the sea because water and substances in the water are exchanged by the change of tides with the bordering coastal area. The effluent from the seaweed system flows directly to the coastal lagoon, reducing the nutrient and sediment load in the lagoon. The seaweed cultivation does not consume industrial auxiliary chemicals, therefore none are released into the water basin. The intensification of seaweed farming might encourage disease outbreaks, similar to what is seen with agricultural plagues, or even cause a decrease in the genetic diversity of local seaweed stocks [44]. By using only local species, there is no risk of biological contamination or invasive species.

In the current study, the impact of fish aquaculture was not included in the assessment, because of the subdivision approach. Fishmeal, sourced from forage fish species, is a common component in sea bass and sea bream [45] which may cause biotic resource extraction from the sea and seafloor damage, depending on the fishing technology. It is also included in fish diets on variable levels. The suggested future research on the potential uses of the Ulva spp. residue should include how the Ulva spp. cultivation contributes to a reduction of fishmeal usage. Peixoto et al. [25] also recommends studying the application of seaweed components in the fish diet, instead of the whole Ulva spp.

Likewise, modelling the impact of the IMTA system, where excess nutrients of the fish farm are input to the seaweed cultivation can be improved. Without an IMTA system, the nutrients would be discharged to the environment and alternative waste water treatment would be needed. 
The improvements suggested in the previous paragraph and the issues presented above call for a broader sustainability assessment: the system boundaries and the scope of sustainability themes could be expanded. A broadened assessment puts greater demands on data collection efforts and possibly increases the uncertainty of the study. In this early innovation stage, the current approach already provides some intuitive predictors of the overall sustainability, such as biomass and starch efficiency, land occupation and global warming potential.

\section{Conclusions}

The study indicates that most of the environmental impact is due to electricity consumption during Ulva spp. cultivation. In addition to directly reducing electricity impacts, improvements in the material efficiency in the production chain will also reduce the impacts of the electricity use, as illustrated with scenario LA2 and the suggested improvements. This study helps to identify both major and minor improvement opportunities during the proof of concept phase of experimental research—along the complete production chain.

This study is the first analysis of the environmental performance of the green seaweed Ulva spp. in polymer applications. Coproducts and waste flows with their nutrient and carbon contents should be tracked in more detail, and other environmental impacts should be assessed in addition to common LCA impact categories. These steps would further improve the understanding of the current scenarios and the proposed improvements, including alternative usages for the hydrolysis residue.

Author Contributions: All authors have contributed to the preparation of this article. The following contributions were provided: Conceptualization, R.J.K.H. and S.W.K.v.d.B.; Methodology, R.J.K.H.; Software, R.J.K.H.; Data Collection, R.J.K.H., A.M.L.-C., H.A. and M.B.; Validation, A.M.L.-C., H.A. and M.B.; Formal Analysis, R.J.K.H.; Writing-Original Draft Preparation, R.J.K.H., S.W.K.v.d.B. Writing-Review \& Editing, F.M., S.W.K.v.d.B.; Supervision, J.M., S.W.K.v.d.B. The authors wish to thank the whole SEABIOPLAS team.

Funding: This work was supported by the European Commission, through the Seventh Framework Program, SEABIOPLAS (grant number 606032).

Conflicts of Interest: Helena Abreu is co-owner and director R\&D and Business Development at AlgaPlus Lda.

\section{References}

1. PlasticsEurope. Plastics-The Facts 2016. 2016. Available online: http://www.plasticseurope.org/ application/files/4315/1310/4805/plastic-the-fact-2016.pdf (accessed on 11 March 2018).

2. Belboom, S.; Léonard, A. Does biobased polymer achieve better environmental impacts than fossil polymer? Comparison of fossil HDPE and biobased HDPE produced from sugar beet and wheat. Biomass Bioenergy 2016, 85, 159-167. [CrossRef]

3. Groot, W.J.; Borén, T. Life cycle assessment of the manufacture of lactide and PLA biopolymers from sugarcane in Thailand. Int. J. Life Cycle Assess. 2010, 15, 970-984. [CrossRef]

4. Vink, E.T.H.; Davies, S. Life Cycle Inventory and Impact Assessment Data for 2014 Ingeo Polylactide Production. Ind. Biotechnol. 2015, 11, 167-180. [CrossRef]

5. Drumright, R.E.; Gruber, P.R.; Henton, D.E. Polylactic acid technology. Adv. Mater. 2000, 12, $1841-1846$. [CrossRef]

6. Masutani, K.; Kimura, Y. Present Situation and Future Perspectives of Poly(lactic acid). In Synthesis, Structure and Properties of Poly(Lactic Acid); Di Lorenzo, M., Androsch, R., Eds.; Springer: Cham, Switzerland, 2017.

7. Juturu, V.; Wu, J.C. Microbial production of lactic acid: The latest development. Crit. Rev. Biotechnol. 2015, 1-11. [CrossRef] [PubMed]

8. Changwichan, K.; Silalertruksa, T.; Gheewala, S.H. Eco-Efficiency Assessment of Bioplastics Production Systems and End-of-Life Options. Sustainability 2018, 10, 952. [CrossRef]

9. Holdt, S.L.; Kraan, S. Bioactive compounds in seaweed: Functional food applications and legislation. J. Appl. Phycol. 2011, 23, 543-597. [CrossRef]

10. Buschmann, A.H.; Camus, C.; Infante, J.; Neori, A.; Israel, Á.; Hernández-González, M.C.; Pereda, S.V.; Gomez-Pinchetti, J.L.; Golberg, A.; Tadmor-Shalev, N.; et al. Seaweed production: Overview of the global state of exploitation, farming and emerging research activity. Eur. J. Phycol. 2017, 52, 391-406. [CrossRef] 
11. Kraan, S. Mass-cultivation of carbohydrate rich macroalgae, a possible solution for sustainable biofuel production. Mitig. Adapt. Strat. Glob. Chang. 2013, 18, 27-46. [CrossRef]

12. Hughes, A.D.; Kelly, M.S.; Black, K.D.; Stanley, M.S. Biogas from Macroalgae: Is it time to revisit the idea? Biotechnol. Biofuels 2012, 5, 86. [CrossRef] [PubMed]

13. Wei, N.; Quarterman, J.; Jin, Y.S. Marine macroalgae: An untapped resource for producing fuels and chemicals. Trends Biotechnol. 2013, 31, 70-77. [CrossRef] [PubMed]

14. Van der Wal, H.; Sperber, B.L.; Houweling-Tan, B.; Bakker, R.R.; Brandenburg, W.; López-Contreras, A.M. Production of acetone, butanol, and ethanol from biomass of the green seaweed Ulva lactuca. Bioresour. Technol. 2013, 128, 431-437. [CrossRef] [PubMed]

15. Korzen, L.; Abelson, A.; Israel, A. Growth, protein and carbohydrate contents in Ulva spp. and Gracilaria bursa-pastoris integrated with an offshore fish farm. J. Appl. Phycol. 2016, 28, 1835-1845. [CrossRef]

16. Marinho, G.; Nunes, C.; Sousa-Pinto, I.; Pereira, R.; Rema, P.; Valente, L.M.P. The IMTA-cultivated Chlorophyta Ulva spp. as a sustainable ingredient in Nile tilapia (Oreochromis niloticus) diets. J. Appl. Phycol. 2013, 25, 1359-1367. [CrossRef]

17. Aehle, W. Enzymes in Industry: Production and Applications, 3rd ed.; John Wiley \& Sons: Weinheim, Germany, 2007.

18. Gupta, R.; Kumar, S.; Gomes, J.; Kuhad, R.C. Kinetic study of batch and fed-batch enzymatic saccharification of pretreated substrate and subsequent fermentation to ethanol. Biotechnol. Biofuels 2012, 5, 16. [CrossRef] [PubMed]

19. Nigam, P.S.; Singh, A. Production of liquid biofuels from renewable resources. Prog. Energy Combust. Sci. 2011, 37, 52-68. [CrossRef]

20. Abreu, M.H.; Pereira, R.; Yarish, C.; Buschmann, A.H.; Sousa-Pinto, I. IMTA with Gracilaria vermiculophylla: Productivity and nutrient removal performance of the seaweed in a land-based pilot scale system. Aquaculture 2011, 312, 77-87. [CrossRef]

21. Troell, M.; Joyce, A.; Chopin, T.; Neori, A.; Buschmann, A.H.; Fang, J.-G. Ecological engineering in aquaculture-Potential for integrated multi-trophic aquaculture (IMTA) in marine offshore systems. Aquaculture 2009, 297, 1-9. [CrossRef]

22. ISO. Environmental Management: Life Cycle Assessment: Principles and Framework ISO 14040; Technical Committee ISO/TC 207; ISO: Geneva, Switzerland, 2006.

23. Langlois, J.; Fréon, P.; Steyer, J.-P.; Delgenès, J.-P.; Hélias, A. Sea-use impact category in life cycle assessment: State of the art and perspectives. Int. J. Life Cycle Assess. 2014, 19, 994-1006. [CrossRef]

24. EC-JRC-IES 2010. International Reference Life Cycle Data System (ILCD) Handbook-General Guide for Life Cycle Assessment-Detailed Guidance, 1st ed.; Publications Office of the European Union: Luxembourg, 2010; p. 417.

25. Peixoto, M.J.; Svendsen, J.C.; Malte, H.; Pereira, L.F.; Carvalho, P.; Pereira, R.; Gonçalves, J.F.; Ozório, R.O. Diets supplemented with seaweed affect metabolic rate, innate immune, and antioxidant responses, but not individual growth rate in European seabass (Dicentrarchus labrax). J. Appl. Phycol. 2016, 28, 2061-2071. [CrossRef]

26. Humbird, D.; Davis, R.; Tao, L.; Kinchin, C.; Hsu, D.; Aden, A.; Schoen, P.; Lukas, J.; Olthof, B.; Worley, M. Process Design and Economics for Biochemical Conversion of Lignocellulosic Biomass to Ethanol: Dilute-Acid Pretreatment and Enzymatic Hydrolysis of Corn Stover; National Renewable Energy Laboratory (NREL): Golden, CO, USA, 2011.

27. Wernet, G.; Bauer, C.; Steubing, B.; Reinhard, J.; Moreno-Ruiz, E.; Weidema, B. The ecoinvent database version 3 (part I): Overview and methodology. Int. J. Life Cycle Assess. 2016, 21, 1218-1230. [CrossRef]

28. IEA 2016. Energy Policies of IEA Countries: Portugal. Paris, France. Available online: https:/ / www.iea.org/publications / freepublications / publication/Energy_Policies_of_IEA_Countries_ Portugal_2016_Review.pdf (accessed on 9 July 2018).

29. Nielsen, P.H.; Oxenboll, K.M.; Wenzel, H. Cradle-to-Gate Environmental Assessment of Enzyme Products Produced Industrially in Denmark by Novozymes A/S. Int. J. Life Cycle Assess. 2007, 12, 432-438. [CrossRef]

30. Goedkoop, M.; Heijungs, R.; Huijbregts, M.A.J.; Schryver Ad Struijs, J.; van Zelm, R. ReCiPe 2008, A Life Cycle Impact Assessment Method Which Comprises Harmonised Category Indicators at the Midpoint and the Endpoint Level, Report I Characterization; Ministry of Housing, Spatial Planning and the Environment (VROM): Den Haag, The Netherlands, 2009; p. 132. 
31. Hansen, B. Determination of nitrogen as elementary N, an alternative to Kjeldahl. Acta Agriculturae Scandinavica 1989, 39, 113-118. [CrossRef]

32. Vink, E.T.; Glassner, D.A.; Kolstad, J.J.; Wooley, R.J.; O'Connor, R.P. Original research: The eco-profiles for current and near-future NatureWorks ${ }^{\circledR}$ polylactide (PLA) production. Ind. Biotechnol. 2007, 3, 58-81. [CrossRef]

33. Hottle, T.A.; Bilec, M.M.; Landis, A.E. Sustainability assessments of bio-based polymers. Polym. Degrad. Stab. 2013, 98, 1898-1907. [CrossRef]

34. Taelman, S.E.; De Meester, S.; Van Dijk, W.; da Silva, V.; Dewulf, J. Environmental sustainability analysis of a protein-rich livestock feed ingredient in The Netherlands: Microalgae production versus soybean import. Resour. Conserv. Recy. 2015, 101, 61-72. [CrossRef]

35. Aitken, D.; Bulboa, C.; Godoy-Faundez, A.; Turrion-Gomez, J.L.; Antizar-Ladislao, B. Life cycle assessment of macroalgae cultivation and processing for biofuel production. J. Clean. Prod. 2014, 75, 45-56. [CrossRef]

36. Van Hal, J.W.; Huijgen, W.; López-Contreras, A. Opportunities and challenges for seaweed in the biobased economy. Trends Biotechnol. 2014, 32, 231-233. [CrossRef] [PubMed]

37. Blunden, G. Agricultural uses of seaweeds and seaweed extracts. In Seaweed Resources in Europe: Uses and Potential; Blunden, G., Guiry, M.D., Eds.; J. Wiley: Chichester, UK, 1992; pp. 63-81.

38. Chapman, V. Seaweeds and Their Uses; Springer Science \& Business Media: Berlin, Germany, 2012.

39. Makkar, H.P.; Tran, G.; Heuzé, V.; Giger-Reverdin, S.; Lessire, M.; Lebas, F.; Ankers, P. Seaweeds for livestock diets: A review. Anim. Feed. Sci. Technol. 2016, 212, 1-17. [CrossRef]

40. Bikker, P.; Krimpen, M.M.; Wikselaar, P.; Houweling-Tan, B.; Scaccia, N.; Hal, J.W.; Huijgen, W.J.; Cone, J.W.; López-Contreras, A.M. Biorefinery of the green seaweed Ulva lactuca to produce animal feed, chemicals and biofuels. J. Appl. Phycol. 2016, 28, 3511-3525. [CrossRef] [PubMed]

41. Yang, Y.; Chai, Z.; Wang, Q.; Chen, W.; He, Z.; Jiang, S. Cultivation of seaweed Gracilaria in Chinese coastal waters and its contribution to environmental improvements. Algal Res. 2015, 9, 236-244. [CrossRef]

42. Radulovich, R.; Umanzor, S.; Cabrera, R.; Mata, R. Tropical seaweeds for human food, their cultivation and its effect on biodiversity enrichment. Aquaculture 2015, 436, 40-46. [CrossRef]

43. Pelletier, N.L.; Ayer, N.W.; Tyedmers, P.H.; Kruse, S.A.; Flysjo, A.; Robillard, G.; Ziegler, F.; Scholz, A.J.; Sonesson, U. Impact categories for life cycle assessment research of seafood production systems: Review and prospectus. Int. J. Life Cycle Assess. 2007, 12, 414-421. [CrossRef]

44. Cottier-Cook, E.; Nagabhatla, N.; Badis, Y.; Campbell, M.; Chopin, T.; Dai, W.; Fang, J.; He, P.; Hewitt, C.; Kim, G. Safeguarding the Future of the Global Seaweed Aquaculture Industry; United Nations University (INWEH) and Scottish Association for Marine Science Policy Brief: Hamilton, ON, Canada, 2016; p. 12.

45. Kousoulaki, K.; Sæther, B.S.; Albrektsen, S.; Noble, C. Review on European sea bass (Dicentrarchus labrax, Linnaeus, 1758) nutrition and feed management: A practical guide for optimizing feed formulation and farming protocols. Aquac. Nutr. 2015, 21, 129-151. [CrossRef] 